\title{
PENGARUH PENERAPAN BIAYA PRODUKSI TERHADAP HARGA JUAL KOPI ARABIKA FLORES (STUDI KASUS PADA PT. PAPA TAKI DI FLORES BAJAWA)
}

\author{
Muh. Indra Fauzi Ilyas \\ Jurusan Manajemen, STIE YPUP Makassar \\ e-mail: fauzi06indra@gmail.com
}

\begin{abstract}
Abstrak
Tujuan dalam penelitian ini adalah untuk mengetahui sejauh mana pengaruh biaya produksi terhadap harga jual kopi arabika Flores. Dalam penelian ini analisis data yang dipergunakan adalah analisis data kuantitatif, dengan menggunakan perhitungan yaitu dengan analisis regresi sederhana dan analisis koefisien determinasi. Dari hasil analisis regresi diperoleh biaya produksi berpengaruh signifikan terhadap harga jual. Sebaiknya dalam pencatatan dan perhitungan biaya produksi harus diperhatikan dan diperhitungkan dengan rinci karena biaya memiliki pengaruh yang sangat besar dalam penetapan harga jual.
\end{abstract}

Kata kunci : Biaya Produksi, Harga jual.

Abstract

The purpose of this study was to determine the extent of the effect of production costs on the selling price of Flores Arabica coffee. In this study the data analysis used is quantitative data analysis, using calculations that are with simple regression analysis and coefficient of determination analysis. From the results of the regression analysis obtained production costs significantly influence the selling price. It is better in recording and calculating the production costs must be considered and calculated in detail because the costs have a very large influence in determining the selling price.

Keywords : Production costs, selling prices.

\section{PENDAHULUAN}

Perusahaan didalam usahanya mempertahankan kelangsungan usaha (going concren), perusahaan biasanya berupaya menentukan harga yang akan memaksimalisasi nilai perusahaan. Harga yang ditentukan untuk sebuah produk akan mempengaruhi pendapatan perusahaan dan pada akhirnya keuntungan yang didapatkan. Mengingat bahwa pendapatan dari penjualan sebuah produk akan sama dengan harga dikalikan dengan kuantitas penjualan. Meskipun harga yang lebih rendah akan mengurangi pendapatan per unit yang diterima, biasanya akan menghasilkan kuantitas penjualan yang lebih tinggi. Harga yang lebih tinggi akan meningkatkan pendapatan per unit yang diterima namun akan menghasilkan kuantitas unit penjualan yang lebih rendah. Dengan demikian perusahaan mempunyai harapan untuk mendapatkan keuntungan maksimum sesuai dengan kondisi yang ada melalui penetapan harga jual.

Menurut Mulyadi (2005) Harga jual adalah besarnya harga yang akan dibebankan kepada konsumen yang diperoleh atau dihitung dari biaya produksi ditambah biaya non produksi dan laba yang diharapkan. Dalam penetapan harga jual perlu dipertimbangkan yang mendalam dan teliti guna memperoleh harga jual yang benar-benar sesuai dengan keinginan dan tujuan perusahaan. Keputusan harga 


\section{AkMen}

jual merupakan keputusan yang sulit, karena faktor-faktor yang mempengaruhi, baik faktor intern maupun ekstern.

Begitu halnya dengan Pabrik Kopi Arabika Flores yaitu salah satu perusahaan yang bergerak dalam bidang penjualan kopi Arabika. Pabrik kopi ini terletak di Flores Bejawa, Kabupaten Ngada. Perusahaan ini berdiri karena ada kemampuan untuk memproduksi suatu barang dan jasa yang dapat memenuhi kebutuhan masyarakat berupa minuman yaitu kopi Arabika. Perusahaan kopi ini hanya memproduksi dan menjual satu jenis produk kopi arabika. Untuk memenuhi selera masyarakat akan kopi arabika Flores, perusahaan dituntut untuk bisa menghasilkan barang dan jasa yang bernilai dan berkualitas baik. Hal ini bertujuan untuk menghadapi persaingan antar perusahaan yang memproduksi produk sejenis.

Sebagai perusahaan manufaktur biaya dibedakan menjadi biaya produksi dan biaya non produksi. Biaya yang dikeluarkan harus diklasifikasikan secara jelas, sehingga memungkinkan dalam penentuan harga jual produksi secara teliti. Perusahaan yang tumbuh dan berkembang adalah perusahaan yang dapat bekerja dengan produktifitas dan efisiensi yang tinggi agar perusahaan dapat memproduksi dengan tepat jumlah, tepat waktu, dan biaya serendah mungkin.

Dalam keadaan tersebut pada umumnya masing-masing perusahaan tidak dapat secara langsung mempengaruhi tinggi rendahnya harga jual produk atau jasa yang di hasilkannya. Harga jual lebih banyak ditentukan oleh kekuatan antara permintaan dan penawaran produk jasa tersebut di pasaran sebaliknya, bagi perusahan yang dihadapkan pada masalah bagaimana menentukan harga jual produk atau jasa yang di hasilkannya.

Penelitian sebelumnya yang dijadikan sebagai pedoman perbedaan dengan penelitian yang akan dilakukan yaitu Nani Suryani (2005), Pengaruh Biaya Overhead Pabrik Terhadap Harga Jual. Studi kasus pada perusahaan Meubel Budi Famili Ciamis. Hasil yang didapat dari penelitian ini menunjukan bahwa biaya overhed pabrik berpengaruh signifikan terhadap harga jual produk. Selain itu Yunita Puspaningru (2006), Pengaruh Biaya Produksi Terhadap Harga Jual Studi kasus pada perusahan Gajah. Dari hasil penelitian dan pembahasan ini, bahwa biaya produksi memiliki pengaruh yang kuat dan besar terhadap harga jual yaitu sebesar $92 \%$ dan sisanya sebesar $8 \%$ dipengaruhi oleh variabel lain, seperti permintaan di pangsa pasar dan persaingan pasar.

Berdasarkan latar belakang masalah yang dikemukakan sebelumnya, maka rumusan masalah dalam penelitian ini adalah Apakah biaya produksi berpengaruh terhadap harga jual pada pabrik kopi Arabika?

Adapun tujuan dalam penelitian ini adalah untuk mengetahui sejauh mana pengaruh biaya produksi terhadap harga jual kopi arabika Flores.

Kegunaan yang ingin dicapai dalam penelitian ini adalah untuk memperoleh pengetahuan yang luas tentang biaya produksi dan penentuan harga jual. Hasil penelitian diharapkan mampu menjadikan sebagai bahan masukan dan pertimbangan bagi manajemen untuk diimplementasikan dalam menentukan besaran harga untuk meningkatkan penjualan dan kepuasan konsumennya dimasa sekarang maupun dimasa yang akan datang. Selsin itu jiga 
sebagai bahan referensi bagi peneliti lainnya yang bermaksud mengadakan penelitian yang sama.

\section{Tinjauan Literaur \\ Biaya Produksi}

Menurut Mulyadi (2000), biaya produksi merupakan biaya-biaya yang terjadi untuk mengelolah bahan baku menjadi produk jadi yang siap untuk dijual. Adapun biaya produksi adalah biaya yang dikeluarkan untuk mengelolah bahan baku menjadi prodak selesai, Sutrisno (2009). Sedangkan menurut Hansen (2004), biaya produksi adalah biaya yang berkaitan dengan pembuatan barang penyediaan jasa.

Maka dapat disimpulkan bahwa biaya produksi adalah biaya yang berhubungan dengan produksi dan harus di keluarkan untuk mengelolah dan membuat bahan baku menjadi produk jadi yang siap untuk di jual.

Menurut Mulyadi (2009), Dalam Akuntansi Biaya penggolongan biaya ditentukan atas dasar tujuan yang hendak dicapai. Dengan penggolongan tersebut biaya dapat digolongkan menurut: Penggolongan biaya menurut objek pengeluaran. Menurut cara ini penggolongan biaya berdasarkan atas nama objek pengeluaran. Penggolongan biaya menurut fungsi pokok dalam perusahaan Dalam hal ini biaya dapat dikelompokan menjadi tiga kelompok yaitu:

a. Biaya produksi, yaitu biaya-biaya untuk mengelolah bahan baku menjadi produk jadi yang siap dijual. Biaya ini terdiri dari biaya bahan baku, biaya tenaga kerja dan biaya overhead pabrik

b. Biaya pemasaran, merupakan biaya yang terjadi untuk melaksanakan kegiatan pemasaran produk c. Biaya administrasi dan umum, yaitu merupakan biaya untuk mengkoordinir kegiatan produksi dan pemasaran produk.

Bahan baku yang digunakan dalam proses tersebut dapat diperoleh melalui pembelian atau dari pengolahan sendiri. Sebelum perusahaan melakukan proses produksi pada umumnya terlebih dahulu menetapkan jumlah kebutuhan bahan baku yang digunakan

Untuk menentukan harga pokok bahan yang dipakai menurut Mulyadi (2009) adalah :

a. Metode identifikasi khusus.

Dalam metode ini perlu dipisahkan tiap jenis barang berdasarkan harga pokoknya dan untuk masing-masing kelompok dibuatkan kartu persediaan tersendiri dengan diberi tanda khusus pada harga bahan yang dibeli.

b. Metode masuk pertama keluar pertama.

Dalam metode ini harga pokok bahan baku yang dibebankan sesuai dengan urutan terjadinya. Apabila ada pemakaian bahan baku harga pokoknya adalah harga pokok terdahulu diusul yang berikutnya. Selanjutnya persediaan akhir dibebankan pada harga pokok akhir

c. Metode masuk terakhir keluar pertama

Dalam metode ini bahan baku yang disusul dengan yang masuk sebelumnya persediaan akhir akan dibebankan pada pembelian yang pertama dan berikutnya.

d. Metode rata-rata bergerak.

Dalam metode persediaan bahan baku yang ada digudang dihitung harga pokok rata-ratanya dengann cara membagi total harga pokok rata-rata persatuan yang baru

e. Metode biaya standar. 


\section{AkMen}

Dalam metode ini bahan baku yang dibeli dicatat sebesar harga standar, yaitu harga taksiran yang mencerminkan harga yang diharapkan terjadi pada masa yang akan datang.

f. Metode rata-rata harga pokok bahan pada akhir bulan.

Dalam ini pada akhir bulan dihitung harga pokok rata-rata persatuan ini kemudian digunakan untuk menghitung bahan baku yang diserahkan oleh bagian gudang ke bagian produksi.

Biaya tenaga kerja untuk fungsi produksi dibagi dalam dua bagian yaitu

a. Biaya tenaga kerja lansung yaitu biaya tenaga kerja pabrik yang lansung berhubungan dengan proses produksi

b. Biaya tenaga kerja tidak lansung, yaitu biaya tenaga kerja yang secara tidak lansung berhubungan dengan pengerjaan produk, baik tenaga itu bekerja dengan tenaga kerja sendiri maupun dengan mesin.

\section{Harga Jual}

Harga jual adalah besarnya harga yang akan dibebankan kepada konsumen yang diperoleh atau dihitunng dari biaya produksi ditambah biaya non produksi dan laba yang diharapkan (Mulyadi, 2005).

Menurut Aliminsyah \& Padji, (2003) harga jual (selling price) adalah harga jual meliputi biaya yang dikeluarkan untuk produksi dan distribusi, ditambah dengan jumlah laba yang di inginkan.

Maka disimpulkan bahwa harga jual adalah besarnya harga yang dibebankan atau dikeluarkan untuk produksi tambah biaya non produksi dan jumlah laba yang di inginkan.
Menurut Tjiptono (2005), pada dasarnya ada empat jenis tujuan penetapan harga yaitu:

1. Tujuan Berorientasi Pada Laba.

Asumsi teori ekonomi klasik menyatakan bahwa setiap perusahaan selalu memilih harga yang dapat menghasilkan laba paling tinggi. Tujuan ini dikenal dengan istilah maksimisasi laba.

2. Tujuan Berorientasi Pada Volume. Selain tujuan berorientasi pada laba, ada pula perusahaan yang menetapkan harganya berdasarkan tujuan yang berorientasi pada volume tertentu atau yang biasa dengan istilah volume pricing objectives. Harga ditetapkan sedemikian rupa agar mencapai target volume penjualan. Tujuan ini banyak diterapkan oleh perusahaan penerbangan, lembaga pendiddikan, perusahan tour dan travel, pengusaha bioskop dan pemilik bisnis bertujuan lainnya,serta menyelenggarakan seminar. Bagi sebuah perusahaan penerbangan ,biaya penerbangan untuk satu pesawat yang terisi penuh maupun hanya terisi separuh tidak bnyak berbeda. Oleh karena itu, banyak perusahaan penerbangan yang berupaya memberikan isentif berupa harga spesial agar dapat meminimalisasi jumlah kursi yang tidak terisi.

\section{Faktor - faktor Penentuan Harga Jual}

Secara umum ada dua faktor utama yang perlu dipertimbangkan dalam menetapkan harga Kotler dan Amstrong (2002) yaitu faktor internal perusahaan dan faktor eksternal perusahaan.

a. Faktor Internal Perusahaan

1. Tujuan pemasaran 


\section{AkMen}

Faktor utama yang menetukan dalam penetapan harga adalah tujuan pemasaran perusahaan. Tujan tersebut bisa berupa maksimisasi laba, mempertahankan kelansungan hidup meraih pangsa pasar yang besar, menciptakan kepemimpinan dalam hal kualitas, mengatasi persaingan, melakukan tanggung jawab sosial.

\section{Strategi Bauran Pemasaran}

Harga hanyalah salah satu komponen dari bauran pemasaran. Oleh karena itu harga perlu dikoordinasikan dan saling mendukung dengan bauran pemasaran lainnya, yaitu produk, distribusi dan promosi.

\section{Biaya}

Biaya merupakan faktor yang menentukan harga minimal yang harus ditetapkan agar perusahan tidak mengalami kerugian. Oleh karena itu setiap perusahaan pasti menaruh perhatian besar pada aspek struktur biaya ( tetap dan variabel ) serta jenis - jenis biaya lainnya,seperti out - of - pocket cost,incremental cost, opportunity cost, dan replacement cost .

b. Faktor Lingkungan Eksternal

1. Sifat Pasar dan Permintan

Setiap perusahaan perlu memahami sifat pasar dan permintaan yang dihadapinya, apakah termasuk pasar persaingan sempurna, persaingan monopolistik, oligopoli atau monopoli. Faktor lain yang tidak kalah pentingnya adalah elastisitasnya permintaan.

2. Persaingan
Ada lima kekuatan pokok dalam persaingan suatu industri, yaitu persaingan dalam industri yang bersangkutan, produk substitusi, pemasok, pelanggan dan ancaman pendatang baru.

\section{Penjualan}

Penjualan adalah pendapatan lazim dalam perusahaan dan merupakan jumlah kotor yang dibebankan kepada pelanggan atas barang dan jasa (Henry Simamora,2000:24). Menurut Kusnadi (2000), penjualan (sales) ialah sejumlah uang yang dibebankan kepada pembeli atas barang atu jasa yang dijual.

Sedangkan menurut Marom (2000) penjualan adalah suatu penjualan barang dagangan sebagai usaha pokok perusahaan dan biasanya dilakukan secara teratur.

Kesimpulan dari pengertian diatas Penjualan adalah sebuah usaha atau langkah kongkrit yang dilakukan untuk memindahkan suatu produk baik berupa barang atau jasa dari produsen ke konsumen sebagai sasarannya.

\section{Hipotesis}

Hipotesis yang akan diuji dalam penelitian ini berkaitan dengan ada atau tidaknya pengaruh signifikan antara variabel $\mathrm{X}$ (biaya produksi) terhadap variabel Y (harga jual), maka dirumuskan hipotesis sebagai berikut: Biaya Produksi Berpengaruh Terhadap Harga Jual pada Pabrik kopi Arabika Flores.

\section{METODE PENELITIAN}

Lokasi penelitian pada pabrik kopi arabika (PT. Papa Taki), Flores Bejawa, Kabupaten Ngada. Jenis data yang digunakan yaitu data kualitatif dan 


\section{AkMen}

data kuantitatif. Kemudian sumber data yang diperoleh yaitu data primer dan data sekunder.

Metode yang digunakan dalam mengumpulkan data yaitu observasi, wawancara, dokumentasi dan penelitian kepustakaan. Populasi dalam penelitian ini adalah industry kopi di Flores Bajawa dan yang menjadi sampel adalah industri kopi PT. PAPA TAKI yang berlokasi di Flores Bajawa kabupaten Ngada.

Dalam penelian ini analisis data yang dipergunakan adalah analisis data kuantitatif, dengan menggunakan perhitungan yaitu dengan analisis regresi sederhana dan analisis koefisien determinasi.

Persamaan Regresi Sederhana

$\mathrm{Y}=\mathrm{a}+\mathrm{bX}+\mathrm{e}$

Dengan:

$\mathrm{Y}=$ Harga Jual

$\mathrm{a}=$ Intersep (titik potong kurva terhadap

sumbu Y)

$\mathrm{b}=$ Kemiringan (slope)Kurva linier

$\mathrm{X}=$ Biaya produksi

$\mathrm{e}=$ Error term

Uji t digunakan untuk menguji koefisien regresi secara parsial dari variabel independennya. Nilai thitung masing-masing koefisien regresi dapat diketahui dari hasil perhitungan komputer.untuk menentukan nilai tstatistik tabel ditentukan tingkat signifikasi $5 \%$ dengan $\quad \mathrm{df}=(\mathrm{n}-\mathrm{k}-1)$ dimana $\mathrm{n}$ adalah jumlah observasi dan $\mathrm{k}$ adalah jumlah variabel termasuk intersep dengan kriteria uji adalah:

Jika t-hit $>\mathrm{t}$ tabel,maka Ho ditolak

Jika $\mathrm{t}$ hit $<\mathrm{t}$ tabel,maka Ho diterima hipotesisnya yaitu:

$\mathrm{Ho}=\beta 1=0$

$\beta 2=0$

$\begin{array}{lrr}\text { Artinya,tidak } & \text { terdapat } & \text { pengaruh } \\ \text { yang signifikan } & \text { dari } & \text { variabel } \\ \text { independen (X) } & \text { terhadap } & \text { variabel } \\ \text { dependen }(Y)\end{array}$

Koefisien determinasi adalah salah satu nilai statistik yang dapat digunakan untuk mengetahui apakah ada pengaruh antara dua variabel. Koefisien determinasi (r2) dari hasil regresi sederhana menunjukkan tingkat kejelasan yang dapat diberikan oleh model tersebut terhadap perubahan variabel dependen. Secara umum nilai $r$ terletak pada nilai 0 sampai dengan $1(0<\mathrm{r}<1)$. Nilai koefisien determinasi menunjukkan persentase variasi nilai variabel dependen yang dapat dijelaskan oleh persamaan regresi yang dihasilkan.

\section{HASIL DAN PEMBAHASAN Proses Produksi}

Proses pengolahan buah kopi arabika menjadi kopi biji (green bean) secarra umum dapat dibedakan menjadi dua cara, yaitu pengolahan cara kering (Dry Process-DP) dan pengolahan secara basah (Wet Process-WP).Tetapi pengolahan kopi Arabika Flores Bajawa hanya dilakukan dengan cara olah basah (WP) yang langkah-langkahnya telah ditentukan dalam Standar Operasional Prosedur (SOP) oleh MPIG. Langkahlangkah pengolahan kopi AFB dengan metode olah basah adalah sebagai berikut:

1. Buah Petik Masak (Merah) Dari Petani.

Untuk memperoleh poduk kopi AFB yang bermutu tinggi diperlukan bahan baku kopi buah merah yang sehat dan segar.

2. Sortase Buah Hingga $95 \%$ Buah Merah.

Kopi gelondong merah perlu disortir untuk memisahkan buah hijau dan kuning serta buah setengah kering dan kering sehingga diperoleh minimum $95 \%$ buah masak (merah) yang sehat dan segar.

3. Perambangan Untuk Memisahkan Buah Yang Terapung. 
Buah merah yang terapung saat perambngan dalam air tergolong dalam kategori buah cacat sehingga perlu dipisahkan.

4. Pengupasan Kulit Buah (Pullper)

Pengupasan kulit buah dilakukan dengan menggunakan mesin pengupas (pullper).

5. Fermentasi Selama 12-18 Jam.

Fermentasi dapat dilakukan dalam bak fermentasi, ember atau karung selama 12 sampai 18 jam. Tujuan fermentasi adalah untuk memperkuat cita rasa dan aroma.

6. Pencucian Dan Perambangan Biji Terapung.

Pencucian dilakukan dengan menggunakan tenaga mesin untuk mengeluarkan lendir dan kotoran yang menempel pada biji kopi. Setelah dicuci, biji kopi perlu dirambang untuk memisahkan biji yang masih terapung.

7. Penjemuran Dan Sortase Untuk Memisahkan HS Yang Rusak Dan Sisa Kulit Kulit Buah

a. Untuk produk HS basah dijemur sampai kadar air $40-60 \%$ kemudian disortir untuk memisahkan HS yang rusak/cacat lalu dipasarkan (ekspor). Produk Kopi HS basah akan dipasarkan dalam bentuk literan yang dikemas dalam karung berukuran 60 liter dengan harga per liter $\mathrm{Rp} 12.000,00$.

b. Untuk memperoleh produk HS kering, akan dijemur sampai kadar air 11- $12 \%$ kemudian disortir. Produk HS kering dapat dipasarkan langsung atau diproses lanjut menjadi kopi ose/kopi beras. Kopi HS kering akan dipasarkan dengan harga $\mathrm{Rp} 40.000,00$ sampai $\mathrm{Rp}$ $45.000,00$ per $\mathrm{Kg}$.

8. Pengupasan Kulit Tanduk (Huller)
Selain dipasarkan langsung, HS kering dengan kadar air 11-12\% juga dapat di diproses (dihuller) untuk mendapat produk kopi ose/kopi beras.

9. Pengemasan

Kopi beras yang telah dihuller akan dikemas dalam karung untuk siap dipasarkan, baik untuk ekspor maupun domestik.

10. Pemasaran

Produk Kopi AFB (HS basah, HS kering, dan kopi Ose) akan dikirim kepada konsumen melalui PT. Indocom Persada selaku eksportir Kopi Arabika Flores Bajawa yang berlokasi di Sidoarjo Jawa Timur. Sampai saat ini Kopi AFB hanya dipasarkan di dalam negeri dan Amerika Serikat.

\section{Modal Usaha UPH Papa Taki}

Salah satu syarat utama pendirian suatu usaha adalah ketersediaan meodal. Tanpa modal yang cukup,sebuah perusahaan tidan bisa menjalankan kegiatannya dengan lancar. Modal usaha dapat berasal dari dalam maupun luar perusahaan.

Modal usaha PT. Papa Taki berasal dari dua sumber yaitu:

1. Modal Dalam

Modal ini diperoleh dari pemilik perusahaan.

2. Modal Luar

Modal ini berupa pinjaman dana dari Bank BRI.

\section{Hasil Persamaan Regresi Sederhana}

Dari hasil analisis regresi sederhana dengan bantuan program SPSS release 21 pada penelitian ini diperoleh hasil persamaan regresi yang menyatakan persamaan Pengaruh Biaya Produksi (X) Terhadap Harga Jual (Y) adalah sebagai berikut: 
Tabel 1

Analisis Pengaruh Biaya Produksi Terhadap Harga Jual Coefficients ${ }^{\mathrm{a}}$

\begin{tabular}{|c|c|c|c|c|c|}
\hline \multirow[t]{2}{*}{ Model } & \multicolumn{2}{|c|}{ Unstandardized Coefficients } & \begin{tabular}{|l|} 
Standar \\
dized \\
Coeffici \\
ents \\
\end{tabular} & $T$ & Sig. \\
\hline & B & Std. Error & Beta & & \\
\hline (Constant) & 569034702,723 & 56638201,792 & & 10,047 &, 000 \\
\hline $\begin{array}{ll}1 & \text { BIAYA } \\
& \text { PRODUKSI }\end{array}$ & 4,904 & 465 &, 958 & 10,537 &, 000 \\
\hline
\end{tabular}

a. Dependent Variable: HARGA JUAL

Dari hasil analisis regresi tersebut diperoleh persamaan Pengaruh Biaya Produksi (X) Terhadap harga jual (Y) yaitu : $\mathrm{Y}=569034701,723+4,904$ dan nilai profitabilitas sebesar 0,000 lebih kecil dari 0,05 . Artinya biaya produksi berpengaruh signifikan terhadap harga jual.

\section{Koefisien Determinasi (r2)}

Tabel 2

Model Summary
\begin{tabular}{|l|l|l|l|l|}
\hline Model & R & R Square & $\begin{array}{l}\text { Adjusted } \\
\text { R Square }\end{array}$ & $\begin{array}{l}\text { Std. Error of the } \\
\text { Estimate }\end{array}$ \\
\hline 1 &, $958^{\mathrm{a}}$ &, 917 &, 909 & 60000919,207 \\
\hline
\end{tabular}
a. Predictors: (Constant), BIAYA PRODUKSI

Koefisien determinasi (r2) dari hasil regresi sederhana menunjukan kejelasan perubahan variabel dependen. Maka nilai koefisien determinasi (r2) sebesar 0,917 yang mendekati angka satu, menunjukan bahwa biaya produksi memiliki pengaruh yang sangat besar terhadap harga jual. Pengaruh variabel $(\mathrm{X})$ yaitu biaya produksi terhadap variabel (Y) harga jual adalah sebersar $92 \%$, sedangkan sisanya sebesar $8 \%$ dipengaruhi oleh variabel lain, seperti permintaan dan penawaran, kondisi pasar, persaingan serta selera konsumen akan Kopi Arabika.

Dari persamaan regresi tersebut dapat disimpulkan bahwa setiap adanya kenaikan biaya produksi maka akan diikuti dengan kenaikan harga jual sebesar Rp. 4.904.

\section{Pembahasan}

Pada dasarnya harga jual produk dan jasa ditentukan dari kekuatan permintaan dan penawaran produk dan jasa tersebut dipasarkan.

Dalam penentuan harga jual yang dipengaruhi oleh faktor laba, faktor produk, biaya produksi yang terdiri dari biaya bahan baku, biaya tenaga kerja dan biaya overhead pabrik dan faktor ekstern seperti permintaan di pangsa pasar dan persaingan pasar merupakan faktor-faktor yang mempengaruhi harga jual.

Dari data harga jual pada tabel 1 dapat diperoleh nilai rata-rata tiap bulan sebesar Rp. 1.137.220.000, sehingga dapat diketahui nilai dari harga jual pada bulan Januari, Februari, Maret, April dan Mei di bawah nilai rata-rata karena pada bulan-bulan tersebut terjadi musim hujan yang mengakibatkan kualitas kopi menurun.

\begin{tabular}{|l|l|l|l|}
\hline BULAN & HARGA/ & PENJUALAN/ & HARGA JUAL \\
\hline
\end{tabular}




\begin{tabular}{|l|l|l|l|}
\hline & UNIT & UNIT & \\
\hline Januari & Rp.40.000 & 18.900 & Rp. 756.000 .000 \\
Maret & Rp.40.000 & 24.150 & Rp .864.000.000 \\
April & Rp.40.000 & 26.800 & Rp. 966.000.000 \\
Mei & Rp.40.000 & 27.064 & Rp.1.072.000.000 \\
Juni & Rp.40.000 & 28.700 & Rp.1.082.560.000 \\
Juli & Rp.40.000 & 29.400 & Rp.1.148.000.000 \\
Agustus & Rp.40.000 & 31.100 & Rp.1.176.000.000 \\
September & Rp.40.000 & 31.800 & Rp.1.272.000.000 \\
October & Rp.40.000 & 32.45 & Rp.1.298.080.000 \\
November & Rp.40.000 & 34.300 & Rp.1.372.000.000 \\
Desember & Rp.40.000 & 34.900 & Rp.1.396.000.000 \\
\hline TOTAL & \multicolumn{2}{|c|}{ Sumber : UPH Papa Taki } \\
\hline
\end{tabular}

Sedangkan untuk harga jual kopi di atas hargajual rata-rata perbulan terjadi pada bulan Juni, Juli, agustus, September, Oktober, November dan Desember. Hal ini disebabkan karena pada bulan tersebut bertepatan dengan aktivitas mudik dan hari raya Natal seiring banyak konsumen yang membeli kopi.

\section{KESIMPULAN}

Dari hasil penelitian dan pembahasan ini, maka dapat disimpulkan bahwa biaya produksi memiliki pengaruh yang kuat dan besar terhadap harga jual yaitu sebesar $92 \%$ dan sisanya $8 \%$ dipengaruhi oleh variabel lain seperti permintaan dipangsa pasar dan persaingan pasar.

Biaya yang digunakan untuk dalam penelitian ini adalah biaya bahan baku, biaya tenaga kerja dan biaya overhead pabrik.

\section{SARAN}

Sebaiknya dalam pencatatan dan perhitungan biaya produksi harus diperhatikan dan diperhitungkan dengan rinci karena biaya memiliki pengaruh yang sangat besar dalam penetapan harga jual. Kemudian perusahaan diharapkan dapat memperbaiki kualitas produk agar memiliki dan menarik pembeli dengan cara penelitian kualitas di pangsa pasar supaya perusahaan dapat member pelayanan yang terbaik bagi konsumen.

\section{UCAPAN TERIMA KASIH}

Pada kesempatan ini penulis mengucapkan banyak terima kasih kepada pihak Yayasan Pendidikan Ujung Pandang STIE YPUP Makassar yang telah memberi dukungan financial dalam menyelesaikan penelitian ini.

\section{DAFTAR PUSTAKA}

Mulyadi. 2005. Akuntansi Biaya. Yogyakarta. Akademi Manajemen Perusahaan. YKPN

Suryani N. 2005, Pengaruh Biaya Overhead Pabrik Terhadap Harga Jual. Studi kasus pada perusahaan Meubel Budi Famili Ciamis. Skripsi, Jurusan Manajemen, Univesrsitas Negeri Semarang, Semarang.

Puspaningru Y. 2006, Pengaruh Biaya Produksi Terhadap Harga Jual Studi kasus pada perusahan Gajah. Skripsi, 
AkMen

Jurusan Akuntansi, Univesrsitas Negeri Semarang, Semarang.

Sutirisno .2009. Manajemen Sumberdaya Manusia. Edisi Pertama. Jakarta: kencana Prenada Media Group.

Hansen. 2004. Akuntansi Manajemen. Jakarta: Selemba Empat.

Mulyadi. 2000. Akuntansi Biaya. Yogyakarta. Aditya Media.

Aliminsyah dan Padji. 2003. Kamus Istilah Keuangan Dan Perbankan. Y. Rahma Widyai.

Tjiptono M. 2005. Strategi Pemasaran. Edisi II. Yogyakarta: Andi Offset.

Kotler, Philip and Gary Amstrong. 2012. Prinsip - Prinsip Pemasaran. Edisi 13 Jilid 1. Erlangga. Jakarta.
Volume 16 Nomor 4 Desember 2019

Hal.559-568

e-ISSN : 2621-4377 \& p-ISSN : 1829-8524

Hbmepage: https//e-jurnal.stiendbel-indonesiaacid/index.php/akmen

Simamora. 2000. Akuntansi Basis Pengambilan Keputusan. Jilid 1. Jakarta: Selemba Empat

Kusnadi. 2000. Akuntansi Keuangan Menengah. Malang. Universitas Brawijaya

Abdul Halim dan Bambang Supomo. 2001. Akuntansi Manajemen. Edisi 1. Jakarta: Selemba Empat.

Marom. 2000. Sistem Akuntansi Perusahaan Dagang. Jakarta. : PT. Grasindo

Adisukma. 2000. Akuntansi Biaya. Edisi Ketiga. Universitas Gajah Mada. Yogyakarta 